\title{
Feasibility of Protection Zones for Water Resources in Arid Areas: Case Study; Duyuk Nueimah Shosa Springs, Jericho, Palestine
}

\author{
Marwan Ghanem ${ }^{*}$, Mahmoud Hammad ${ }^{2}$ \\ ${ }^{1}$ Birzeit University, Rammallah, Palestine \\ ${ }^{2}$ IWRM, Bethlehem, Palestine \\ Email: "mghanem@birzeit.edu, mahhammad@yahoo.com
}

Received 22 January 2015; accepted 6 February 2015; published 11 February 2015

Copyright (C) 2015 by authors and Scientific Research Publishing Inc.

This work is licensed under the Creative Commons Attribution International License (CC BY). http://creativecommons.org/licenses/by/4.0/

(c) (i) Open Access

\begin{abstract}
Urbanization and different human-economic activities put increasing pressure on the ground water quality, which is considered as the main drinking water resources in Palestine. Protecting the spring water resources in Palestine is one major issue for the continuity of the availability of the water resources. An economic feasibility study was conducted for the Nuewimah-Shosha-Dyuk spring system in order to assess the economical factor for the induced methodology of the protection zones. The spring system has multiple users from different sectors (i.e., domestic, agriculture, commercial and public use) and multi-year cost benefit analysis technique used to show the feasibility of water protection zones on the long run. The study shows that even in arid areas in Palestine, small quantities are derived from springs-implementation of water protection zones is still feasible; the results of this study emphasize on importance and feasibility of water resources protection zones.
\end{abstract}

\section{Keywords}

Water Protection Zones, Cost Benefit Analysis, Protection Zones Guidelines, Nueimah Spring System, Jericho Area

\section{Introduction}

Protecting current available water resources is of high importance. Implementing water protection zones do not provide additional quantity of water, but protecting the current available water resources. This research aims to

${ }^{*}$ Corresponding author.

How to cite this paper: Ghanem, M. and Hammad, M. (2015) Feasibility of Protection Zones for Water Resources in Arid Areas: Case Study; Duyuk Nueimah Shosa Springs, Jericho, Palestine. Journal of Environmental Protection, 6, 110-117. http://dx.doi.org/10.4236/jep.2015.62013 
provide explanation about the current situation and the importance of water protection zones for water resources in arid areas. For Palestinians, available water resources are opposed to different challenges in terms of quantity and quality. Limited access to water resources, the increase in demand due to high population growth and needs for other growing sectors are the major factors to be taken into consideration. Jericho area is located in the lower part of the Al Qilt and Al Nueimah watersheds that are located in the south-eastern part of the West Bank (Figure 1). They extend from the central mountains of the West Bank in the west to the Jordan River in the east.

Jericho area has high agricultural, tourism and commercial activities. In Jericho area, springs are main natural suppliers for the water used, especially water used for domestic use. Meanwhile, Jericho area is considered as an important area for tourism activities. Deterioration of water quality would require costly treatment and may affect adversely various economic activities in Jericho area. The majority of water quantities produced from Duyuk, Nueimah and Shosa springs are used for irrigation purposes in Nueimah and Duyuk villages, which are dominated by agricultural activities. According to [2], "The source of fresh water in the area is derived from ground water, which is tapped from the aquifer systems of the shallow Plio-Pleistocene and the deep Cenomanian (East Mountain) aquifers". "Unfortunately, the ground water quality of the shallow aquifer system has been deteriorating in this area for some time. In the Jericho region, for example, dissolved chloride concentrations have increased to more than $2000 \mathrm{mg} / \mathrm{L}$ during the last 30 years". Therefore, there is an urgent need for protecting the water resources as continued groundwater pollution threatens the water supply for all water users. According to [3], groundwater in the lower part area exists in Quaternary Aquifer. It consists mainly of gravels, cobbles and boulders inter-fingering with impermeable layers of saline marl deposits and transported from the western slopes of the Jordan valley forming alluvial fans. The groundwater in this aquifer is stored in gravels zones separated by marls deposits (Figure 2), which are not well defined, either vertically or horizontally. The infiltration of floodwater in wadies is the main source of aquifer recharge during the winter season. Meanwhile, the water quality of this aquifer varies with location. Good groundwater quality occurs near the wadies, where fresh groundwater is available. It is believed that this aquifer is overlaying the Lisan Formation, which is acting

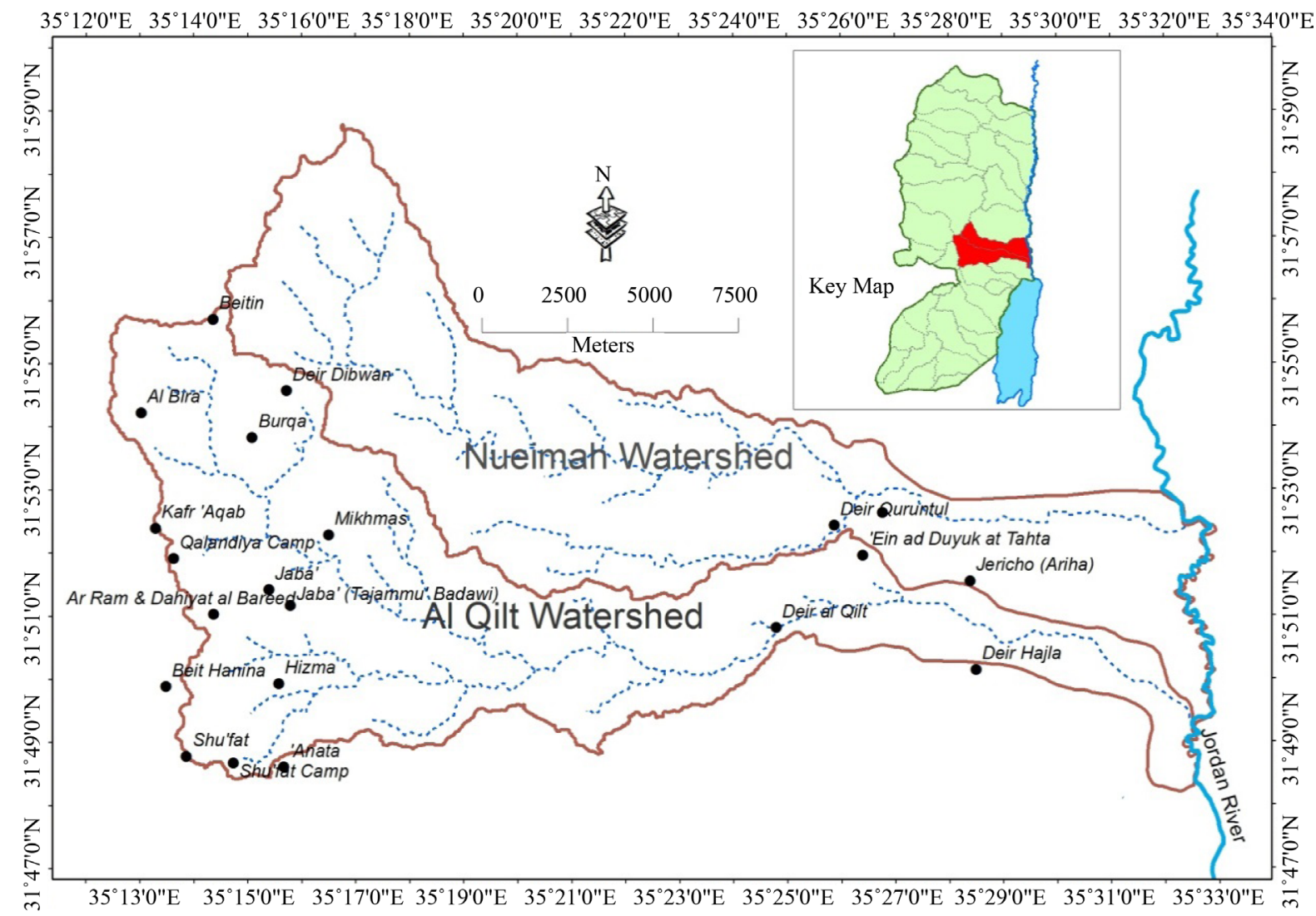

Figure 1. Location map of Nueimah watershed [1]. 


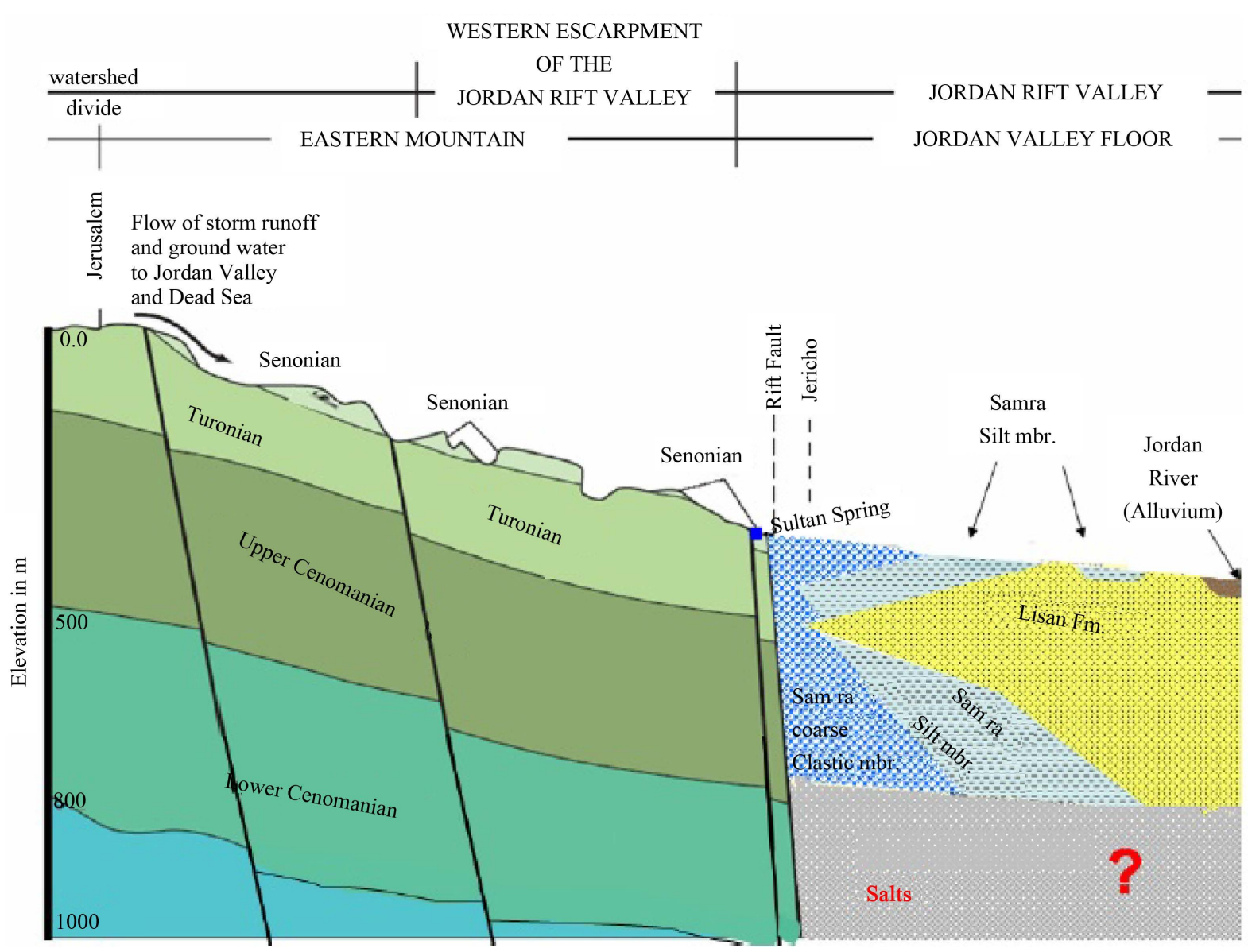

Figure 2. Geological cross section in study area [4].

as impermeable or a very low permeability layer. The general direction of groundwater flow in the Quaternary Aquifer is towards Jordan River and the Dead Sea.

Most areas of the lower part of Nueimah watershed have moderate groundwater vulnerability (Figure 3). The concept of groundwater vulnerability is based on the assumption that the physical environment provides some natural protection to groundwater against human impacts, especially with regard to contaminants entering the subsurface environment [5].

\section{Methodology}

Cost benefit analysis (CBA) is implemented to assess the feasibility of water protection zones; the CBA is made on multi year basis. For each year costs and benefits are calculated. Calculations of costs include the costs of implementing protection zones that are defined according to local guidelines. Implementing protection zones includes constructing monitoring facilities near the water resource may prohibit specific activities such as industrial factories that cause pollution or extensive use of fertilizers in near agricultural activities. The reduction in profit for these activities due to restrictions is considered in the side of costs. On the other hand, benefits are represented by the value of water; many methods for defining the value of water are available in literature such as contingent valuation method... etc. The problem is that such methods depend usually on qualitative data analysis and this would not give an exact value number where a specific numbers are needed in a calculation methodology depending on numerical methods. Also when having the case of water resources located in an arid area the evaluation would be much more complicated and may have serious errors as the value of water is dependent on many dynamic and variable factors such as increasing water demand, increasing economic activities, depletion and scarcity of water... etc. Therefore, to solve the problem of uncertainty of water value, the water tariff to be paid is used as water tariff in Palestine is always lower than the cost of water production and there- 


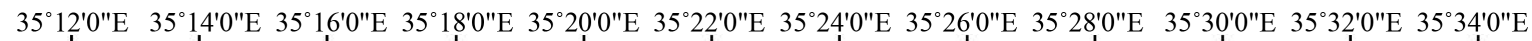

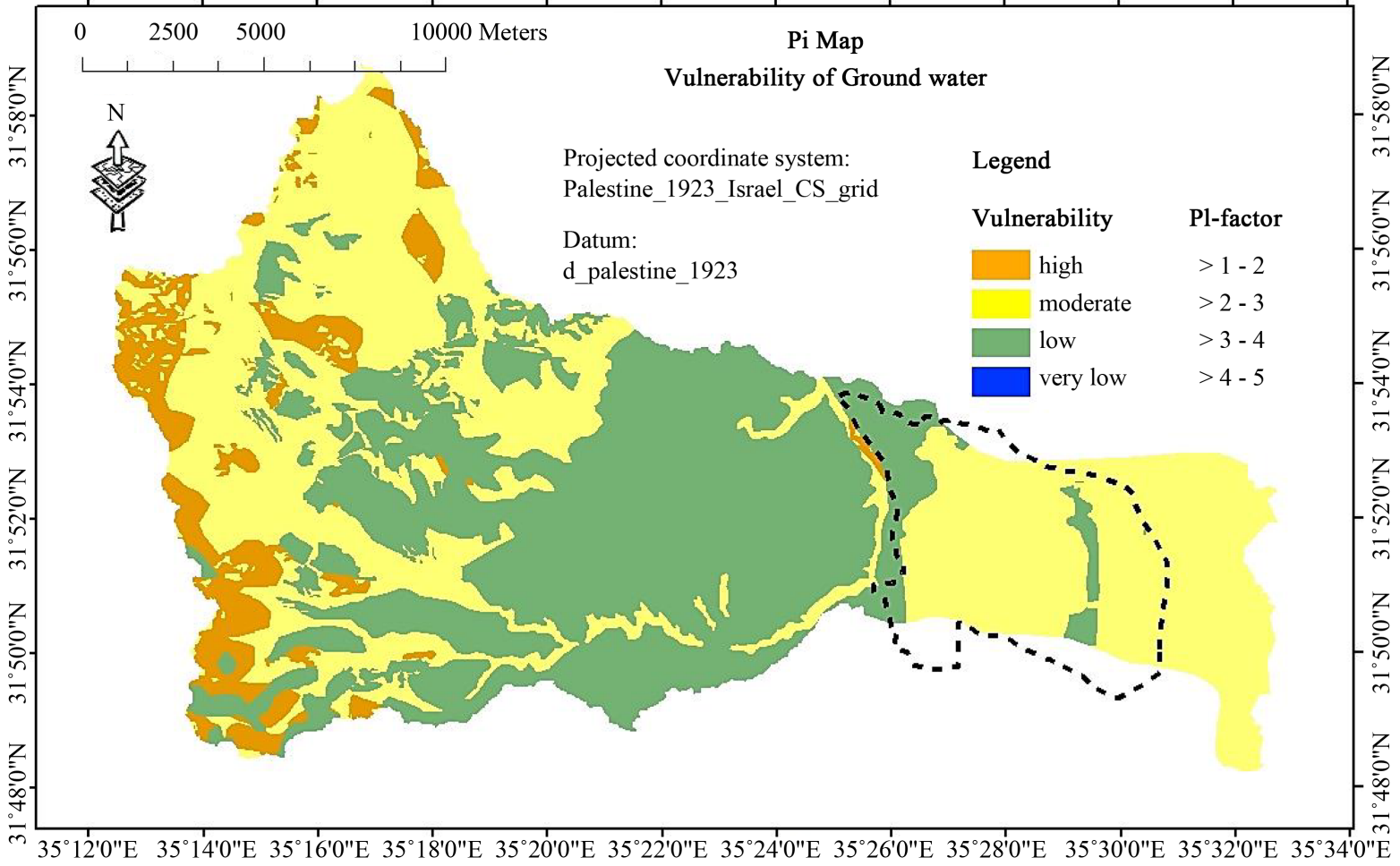

Figure 3. Vulnerability map for groundwater [6].

fore it represents the lower limit of the water value. Calculations of costs and benefits are obtained by transforming all possible running costs and benefits into monetary unit per each cubic meter of water used, while investment costs are annualized (In the case of yearly calculation and if monthly calculation to be used annual values should be changed into monthly values). This transformation is due to the fact that calculation of benefits in this methodology depends on discharge volume used from the water resource by which its future projection is obtained from a previously hydrological numerical model. Like the expected decrease in spring discharge is due to climate change and also for the reason that calculation of benefits is based on water tariff and it is different from sector to another and the weighted average of water price is calculated based on water allocation that may change from one year to another.

\section{Results and Discussions}

\subsection{Guidelines of Protection Zones for Springs in Jericho Area}

There are no current Palestinian guidelines for water protection zones (WPZ), and therefore it is an obstacle for assessment of WPZ locations, yet there are guidelines in Jordan. The Jordanian WPZ guidelines refer to cases where the residence time of water is 50 days. The residence time in Al Qilt watershed is expected to be in the range of 50 - 54 days [7]. Therefore, the Jordanian guidelines can be applied as long as no Palestinian guidelines exist knowing that Palestine and Jordan share the Jordan valley basin. According to Jordanian guidelines, a water resource should be surrounded by three nested zones in which specific activities are prohibited. The three categories of protection zones are as following:

Zone I: It is the closest to water intake and has the strongest restrictions and is defined as 50 meters at least in the upstream direction, 10 meters in the downstream direction and 15 meters at each side. Activities in this zone are totally prohibited and the areas within the protection zone 1 should whenever possible be owned and fenced by the Water Authority.

Zone II: According to Jordanian guidelines [8], "Protection zone II is defined in the view of the hydraulic information. Studies and technical reports provide sufficient knowledge to the water sector experts to estimate 
groundwater flow velocities, residence time and pollutant transport time such that the time needed for the microbiological pollutants to reach the water source is 50 days minimum given that the maximum protection distance in the upstream is $2 \mathrm{~km}$. The distance in the downstream direction should be between 50 and $150 \mathrm{~m}$ depending on the characteristics of the water source. In cases where the dominant geological feature is a Karst aquifer system, vulnerability to pollution mapping, if available, are to be used and technical consultation is sought in that regard".

Zone III: Includes the protection of the entire catchment area. Zones III aims to protect against pollution over long distances, such as contamination by radioactive substances or chemicals which are none or hardly degradable [9].

\subsection{Cost Benefit Analysis of Duyuk, Nueimah and Shosa Springs Protection Zone}

Even though most of the water quantity produced from this springs' group is allocated to agriculture; domestic users are still dependent on water from Duyuk, Nueimah and Shosa springs. Regarding pollutants, there is no major pollution sources are located upper the springs, and only mountains exist, yet some Bedouins are watched very near to springs that may cause pollution effects on water from animal rising (Figure 4). People in Duyuk and Nueimah have also cesspits, yet such cesspits are located lower stream and therefore have no effects on springs' water quality. On the other hand, there is no Israel or Palestinian urban areas located in the near mountains (Figure 5).

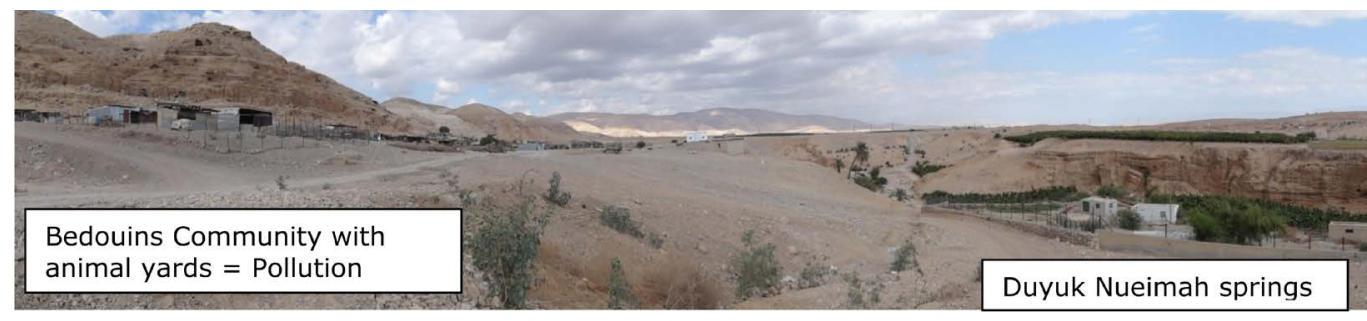

Figure 4. Duyuk and Neuimah springs field photo.

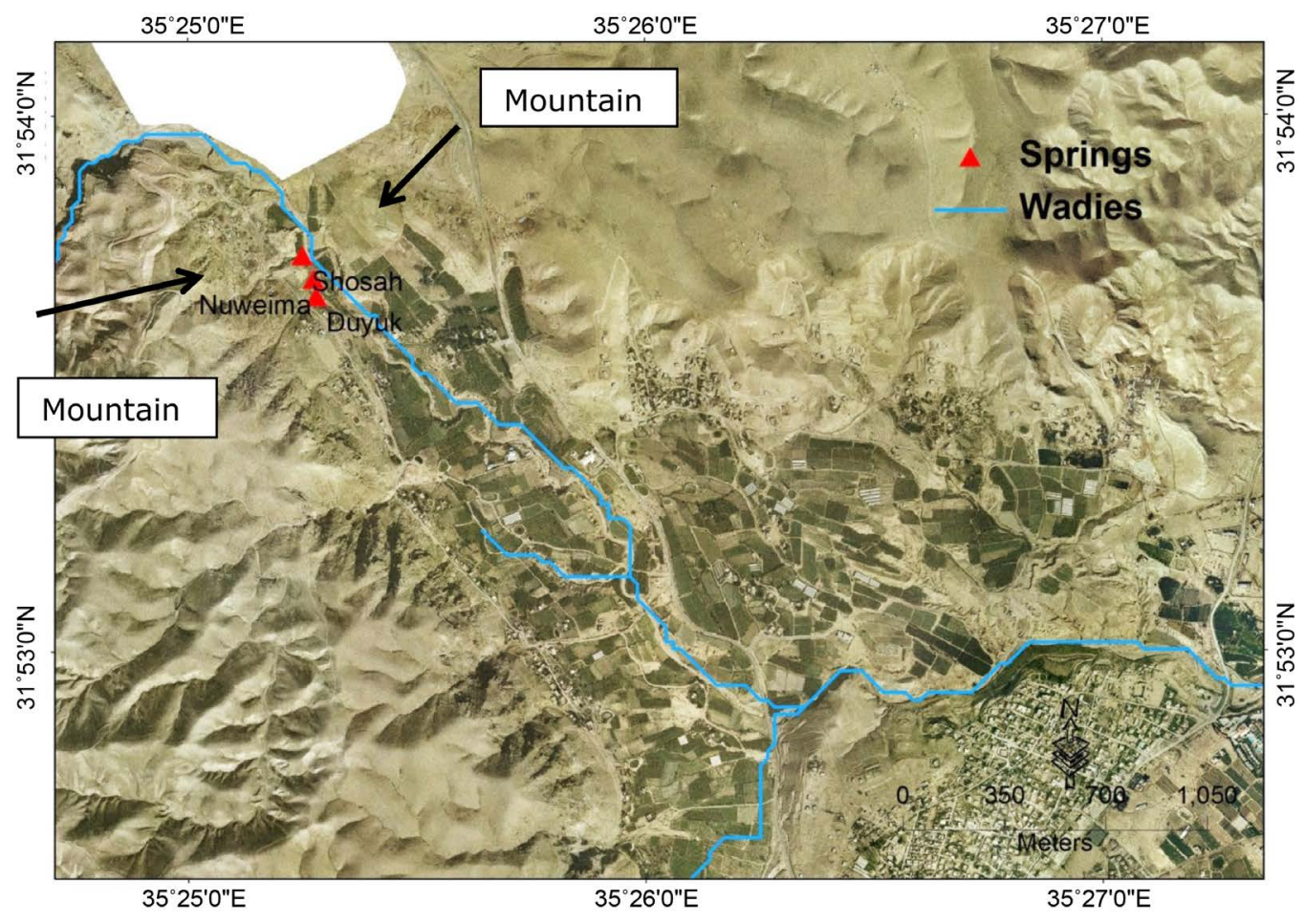

Figure 5. Aerial image for the area of Duyuk, Nueimah and Shosa springs group. 
Domestic users currently demand about $0.5 \mathrm{MCM} / \mathrm{yr}$ and this amount of water is provided to domestic, commercial and public users in the Shosa, Nueimah and Duyuk areas. At present, the domestic water demand is small. Nevertheless, the demand for high-quality water is expected to increase to about $0.9 \mathrm{MCM} / \mathrm{yr}$ in 2031 (Figure 6). Domestic and commercial users pay for water according to different water tariffs (Table 1). Like in the Jericho city, public users do not pay for the water. Nevertheless, the water volumes delivered to these users have an economic value, which is to be considered in estimating the economic value of high-quality water.

The CBA of the proposed water protection zone for Duyuk Nueimah Shosa spring group considers the following cost items (Table 2):

The results of the CBA within the period from 2011 to 2031 are shown in Figure 7 indicating the importance and increasing economic value of precautionary measures for the Duyuk, Nueimah and Shosa springs.
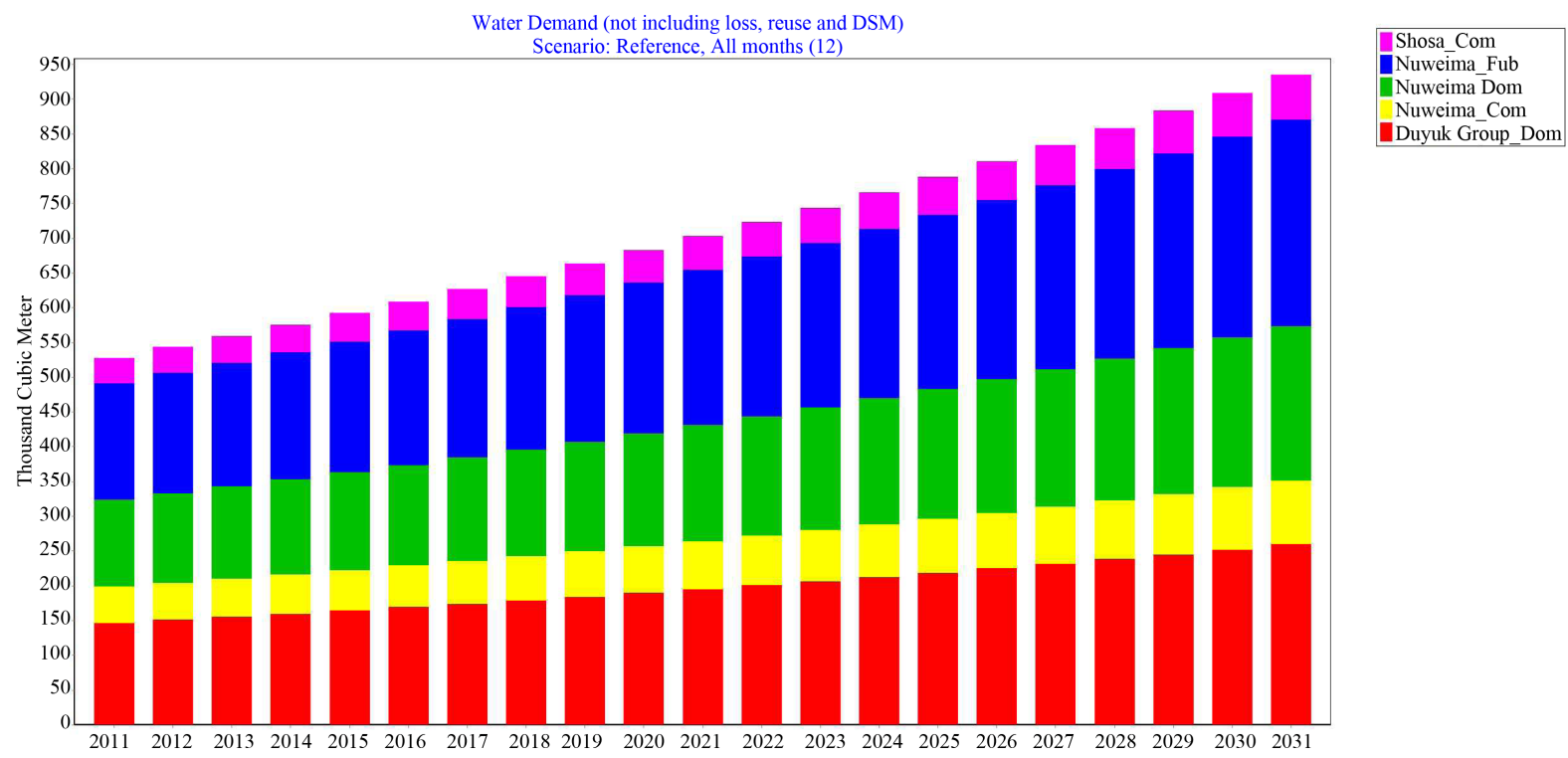

Figure 6. Duyuk, Nueimah and Shosa area water demand for domestic, commercial \& public use in 2011-2031.

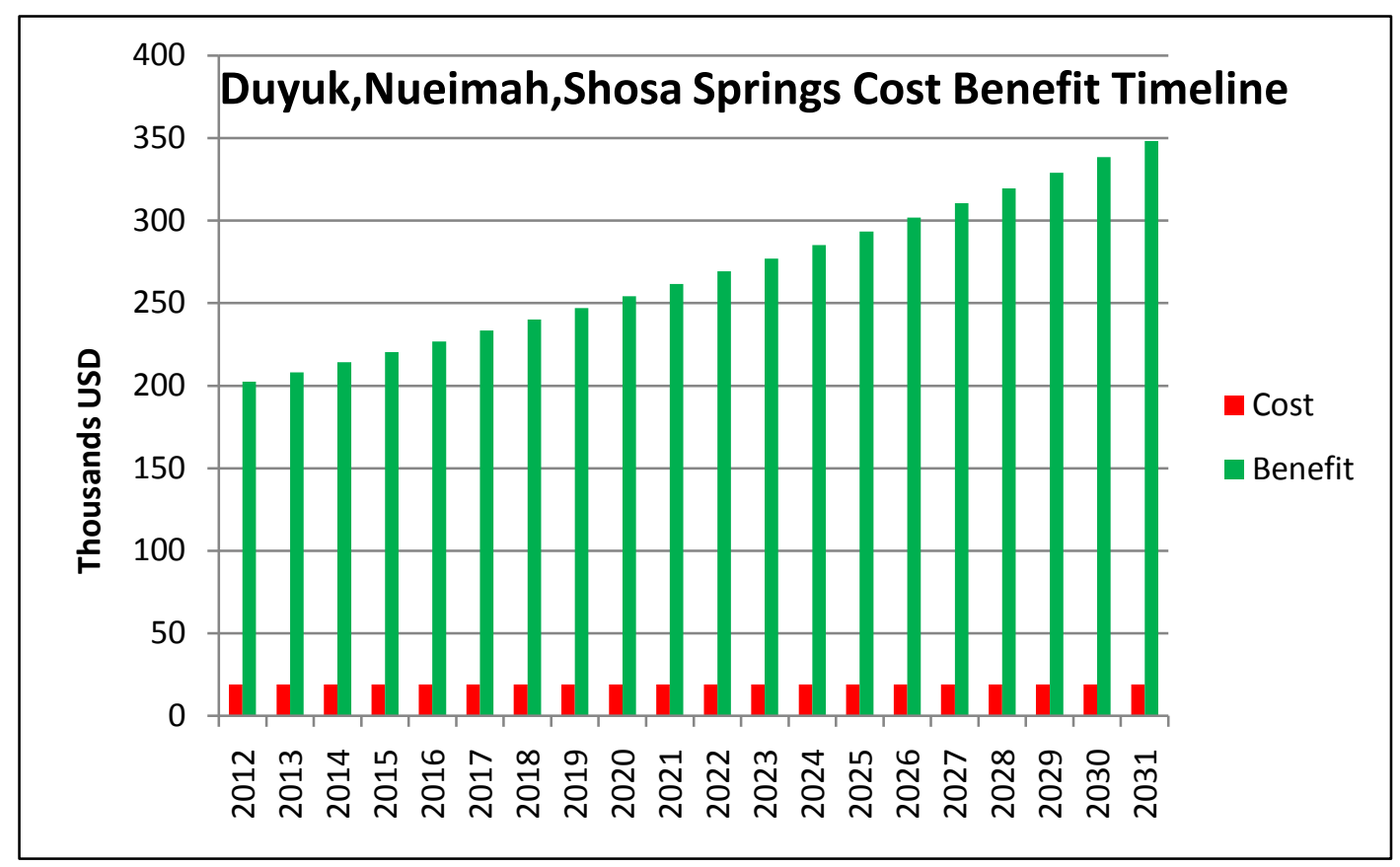

Figure 7. CBA of Duyuk, Nueimah, Shosa springs group water protection zones in 2011-2031. 
Table 1. Domestic and commercial water tariff in Duyuk Nueimah villages.

\begin{tabular}{cccc}
\hline & \multicolumn{2}{c}{ Duyuk Nueimah domestic tariff } & \\
\hline Block no. & Consumption category & Price $\left(\mathrm{NIS} / \mathrm{m}^{3}\right)$ & Price $\left(\mathrm{USD} / \mathrm{m}^{3}\right)$ \\
\hline 1 & $0-100,000 \mathrm{~m}^{3}$ & $2 \mathrm{NIS} / \mathrm{m}^{3}$ & 0.52 \\
\hline Block no. & Duyuk Nueimah commercial tariff & Price $\left(\mathrm{USD} / \mathrm{m}^{3}\right)$ \\
\hline 1 & Consumption category & Price $\left(\mathrm{NIS} / \mathrm{m}^{3}\right)$ & 1.05 \\
\hline
\end{tabular}

Table 2. Summary of cost items for Duyuk Nueimah Shosa springs group water protection zone.

\begin{tabular}{cc} 
Item & Cost (USD/yr) \\
\hline Sign post & 100 \\
Operation, monitoring quality \& hazards & 18,750 \\
Total cost & $\mathbf{1 8 , 8 5 0}$ \\
\hline
\end{tabular}

\section{Conclusion}

The present paper carries out an economic evaluation of water protection zones using cost benefit analysis for the Dyuk-Nueima-Shosa spring system in Jericho area in lower Jordan valley. The results of the analysis show that precautionary measures of pollution to water resources represented by water protection zones can lead to considerable benefits for domestic, commercial and public users. The provision of high-quality water represents the major economic benefit of water protection zones. The reason is the great importance that users attach to this type of water, even if tariffs do not reflect its true value. In cases, where the cost is lower than the benefit, water protection zones are economically worthwhile, i.e. values added and additional gains in societal welfare will emerge. Yet, further investigations are needed with regard to the impacts of safe drinking water supply on the future economic development of communities. More information on the financial implications of water protection zones would be useful as well: Who pays the costs of restrictions in land use, to which extent farmers should get compensation payments. Also investigation is about how and who is going to manage water protection zones. The economic analysis of WPZ at Jericho area in lower Jordan River valley proves that surplus of benefits over the costs can be expected in most cases. Yet, under special conditions, restrictions particularly on agricultural land use (e.g. ban of agro-chemicals) can cause considerable income losses, so that the costs of designing water protection zones may exceed the economic benefits. More investigations in this regard are needed and it is important to note that the cost and benefit numbers are rough approximations. In particular, the economic benefit of high-quality water may be higher, if the water tariffs would represent cost-recovery water prices.

\section{References}

[1] PHG (2010) Water Master Plan for Jericho City. Palestinian Hydrological Group, Jericho.

[2] Marie, A. and Vengosh A. (2001) Sources of Salinity in Ground Water from Jericho Area, Jordan Valley. Ground Water, 39, 240-248. http://dx.doi.org/10.1111/j.1745-6584.2001.tb02305.x

[3] Abdel-Ghafour, D. (2005) Small-Scale Storm Water Harvesting in Wadi El-Qilt Ramallah: Palestinian Water Authority.

[4] Khayat, S.K. (2005) Hydrochemistry and Isotope Hydrogeology in the Jericho Area/Palestine. University of Karlsruhe, Germany.

[5] Vrba, J. and Zoporozec, A., Eds. (1994) Guidebook on Mapping Groundwater Vulnerability. International Contributions to Hydrogeology (IAH), 16, 131 p.

[6] Bastian, D. (2012) RE: PI Map Data. Type to HAMMAD, M.

[7] Ghanem, M. (2013) Discussion about Residence Time in Jericho Area. Personal Communications.

[8] Tarawneh, R. and Margane, A. (2006) Drinking Water Resources Protection Guidelines. Ministry of Water and Irrigation, Amman. 
[9] Margane, A., Schmidt, G., Schelkes, K., Khalifa, N. and Subah, A. (2007) Contributions to the Protection of Water Resources in Jordan.

http://www.bgr.bund.de/EN/Themen/Wasser/Veranstaltungen/iah_2006/presentation_schelkes_pdf.pdf?_blob=public ationFile\&v=2 
Scientific Research Publishing (SCIRP) is one of the largest Open Access journal publishers. It is currently publishing more than 200 open access, online, peer-reviewed journals covering a wide range of academic disciplines. SCIRP serves the worldwide academic communities and contributes to the progress and application of science with its publication.

Other selected journals from SCIRP are listed as below. Submit your manuscript to us via either submit@scirp.org or Online Submission Portal.
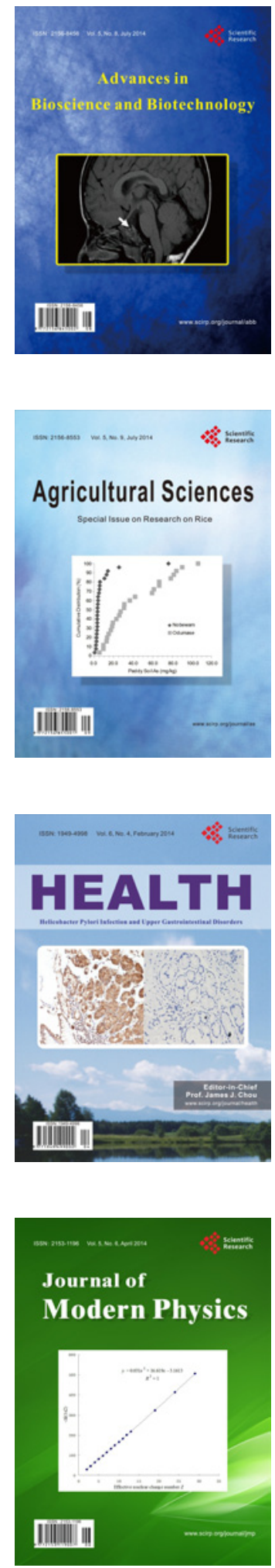
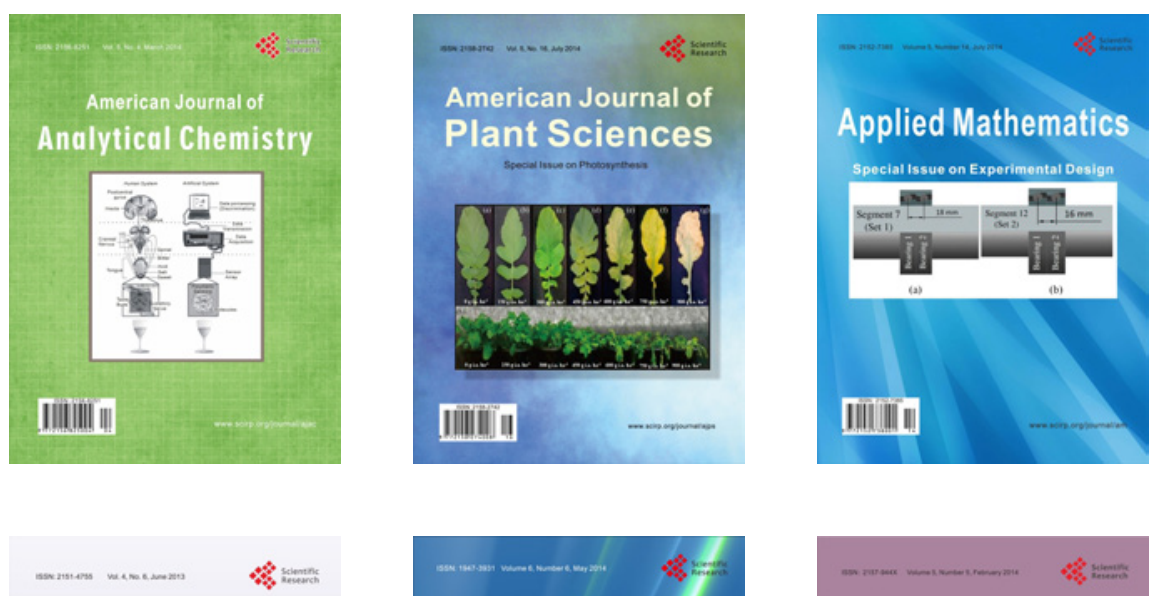

Creative Education
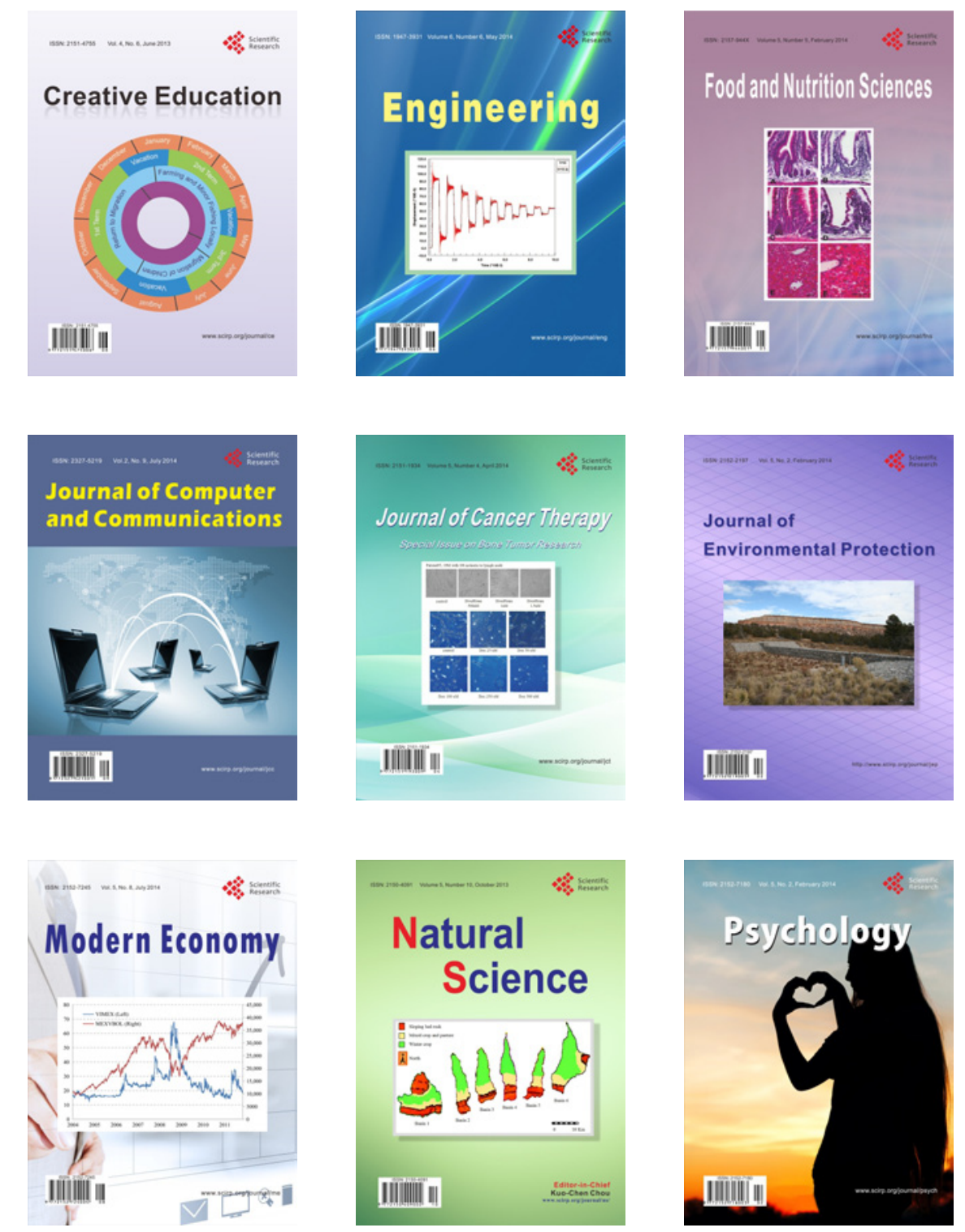